\title{
ANTHROPOLOGICAL WORKING PAPERS
}

\author{
A Series \\ Issued From the Office of \\ The Staff Anthropologist \\ Trust Territory of The Pacific Islands \\ Cuam, M. I.
}

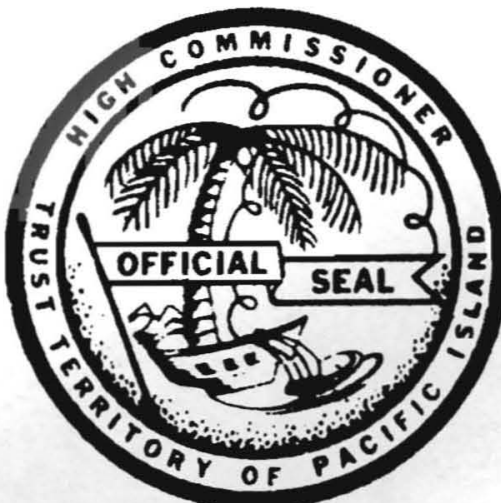

NUMBER 6

TARO CULTIVATION PRACTICES AND BELIEFS

PART I. THE WESTERN CAROLINES

TARO CULTIVATION IN PALAU

Robert K. McKnight and Adalbert Obak

TARO CULTIVATION IN YAP

Dai You Kim and Francis Defngin

GREGG M. SINCLAIR LIBRARY

UNIVERSITY OF HAWAII

January 1960 
A NTHROPOLOGICAI WORKING PAPERS

\author{
A Series \\ Issued from the Office of \\ The Staff Anthropologist \\ Trust Territory of the Pacific Islands \\ Guam, M. I.
}

\author{
Number 6 \\ TARO CULTIVATION PRACIICES AND BELIEFS \\ PART I. THE WESTERN CAROLINES \\ TARO CULTIVATTON IN PALAU \\ Robert $\mathrm{K}$. McKnight and Adalbert Obak \\ TARO CULTIVATION IN YAP \\ Dai You Kim and Francis Defngin
}

January 1960 
TABLE OF CONTENTS

Page No.

Foreword by the Editor.................... ii

I. TARO CULTIVATION IN PALAU.................. I By Robert K. McKnight and Adalbert Obak

II. TARO CULTIVATION IN YAP.................. L 48 By Dai You Kim and Francis Defngin 
FOREWORD

This paper is the second in a number of scheduled papers on ethnographic aspects of subsistence crops of the Trust Territory of the Pacific Islands.

As indicated in the first paper of this subsistence crop series, these papers do not attempt to be botanical guides. An attempt has been made to check botanical names and agricultural aspects and in this respect, the Director of Agriculture and members of his staff have given valuable advice and aid.

The paper on taro cultivation practices is being issued In two parts; the present section, Part I, dealing with the region known as the Western Carolines. Part II will be devoted to the Eastern Carolines and the Marshall Islands.

The paper on taro cultivation in Yap District is based on an earlier paper prepared by Mr. Dai You Kim,former agriculturist of Yap District. It has been rewritten by the Assistant Anthropologist of Yap District and considerable new material added.

John E. deYoung

Staff Anthropologist

Guam

January, 1960 


\section{TABLE OF CONTENTS}

\section{Page No.}

1. Types of Taro

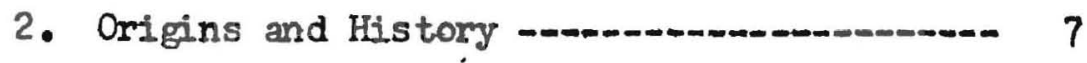

3. Social Value of Taro in Palauan Society -.. 8

Prebirth-_._. 9

Birth-_-_._- 10

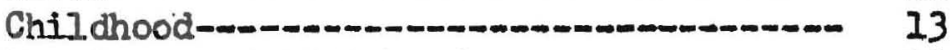

Marriage and Aculthood-.................. 13

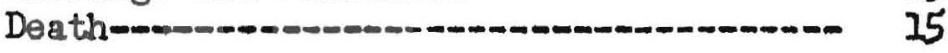

4. Economic Units and the Taro Garden-_....-. 20

5. Conditions Relevant to Planting-_-_._-_-_-_ 26

Planting Seasons-ano 26

Soil Preparation-_. 28

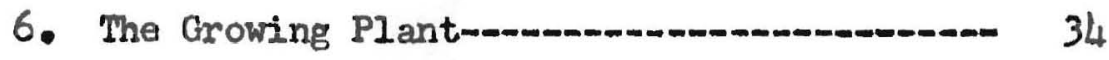

7. Magic and the Myth of Milad-_._............ 38

8. Other Regional Differences: The Southwest

Islands

9. Glossary of Non-English Terms_............... 43 


\section{TARO CULTIVATION IN THE PALAU DIS TRICT}

The taro swamp is the mother of Iife. In Palau the wealth of this swamp is the kukau (Colocasia esculenta) carefully cultivated in sump-like plats that collect the richness of the earth washed down from the low surrounding hills. Kukau is the prestige food and, despite its general consumption, it is sometimes thought of as a gift from the women of Palau to their husbands. As a gift its preparation, from planting to serving, is ritualized and formalized, Its successful cultivation is a matter of matronly pride, and its varieties are often given names that honor the women who find them. (See Fig. \#2, page 4).

In addition to kukau, there is a work-a-day tuber, brak (Cyrtosperma chamissonis), a huge hardy aroid that grows in untended odds and ends of cultivated plats, or haphazardly, in swamps that are lying fallow. Brak, lacking the prestige of kukau, is thought of by some Palauans as food for children and women and as a natural product of the land, like roots and shell foods, rather than a jealously produced crop. For example, unlike kukau, there are few varieties of brak, about eleven all told, and no special effort is made to increase the number of varieties by transplanting brak plants growing in 


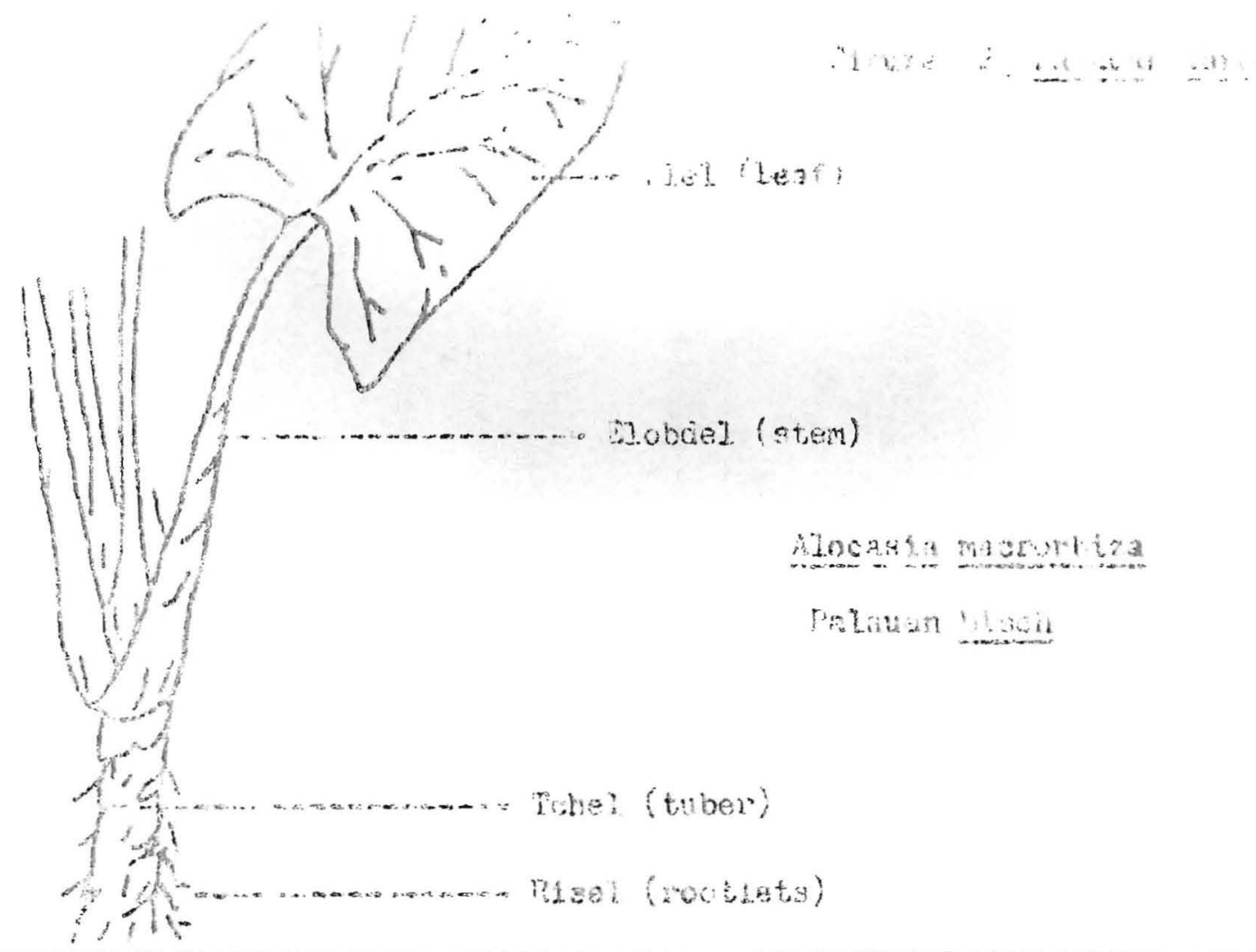

$0 b 3 e ?$
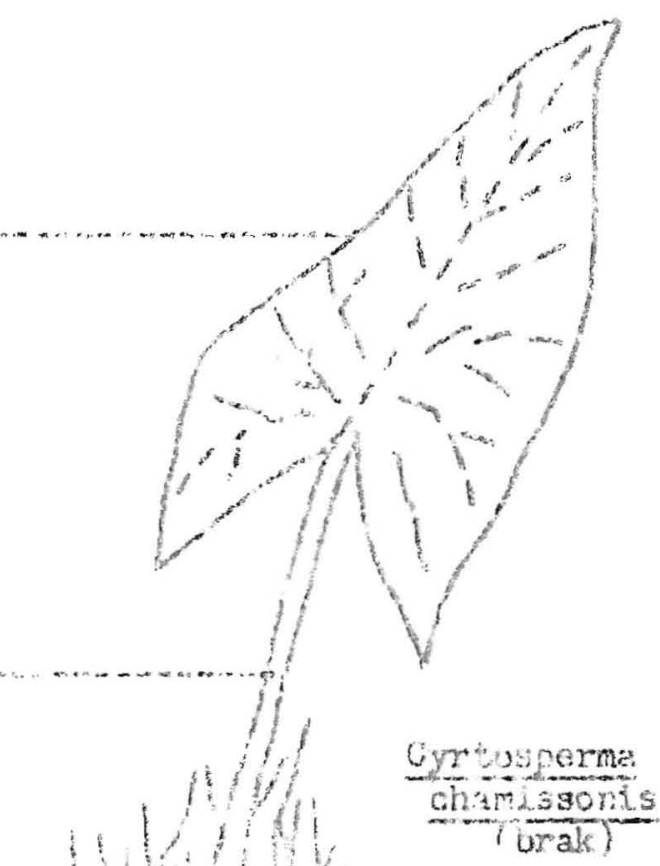

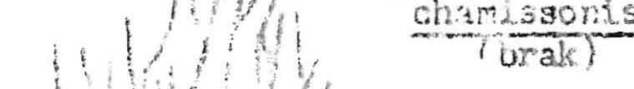

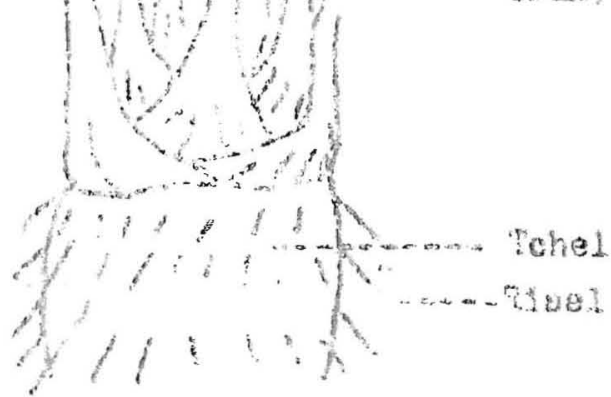

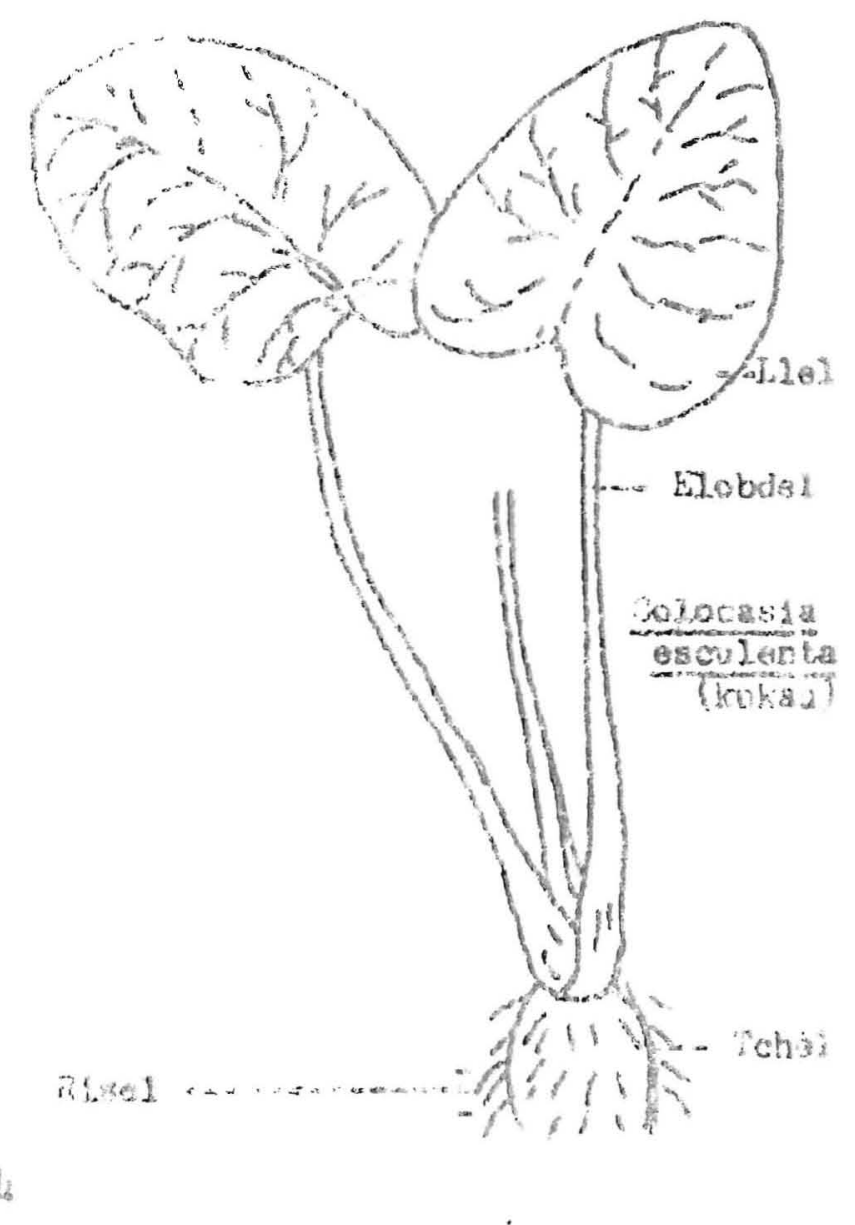


the bush. (See Fig. \#2, page 4).

Bisch (Alocasia macrorbiza), a third plant of Palau commonly called a taro, occurs in about seven itchy varieties. One of these, eliiche, is so strong in itchy poison, probably a saponin, that it is not considered palatable. All varieties rank below brak in quantity consumed and in culinary appreciation. Like brak, bisch is considered a native plant and most varieties are dealt with accordingly. Except on the low islands of Kayangel and Peleliu, where other tubers do not grow well, the bisch plant is seldom cultivated and is harvested where a stand occurs. An exception is bisch era Saipan, a nonitchy variety introduced during the Japanese administration and commonly raised as a border crop in tapioca gardens. (See Fig. \#2, page 4).

A fourth tuber, which Palauans call bisch era ruk ("bisch of the dance", so called because it was brought to Palau by the Japanese in about 1920 from Truk and the Palauans observed that Trukese, then working in the Angaur phosphate mines, were excellent dancers) is the West Indian yautia (Xanthosoma sagittifolium). A non-itchy tuber, characterized by a rootstock with numerous branching corms, bisch ere ruk is cultivated in Palau as a border crop and occasionally as a separate stand. There are, in addition, a few aroids, comonly included as taro, which are direct importations from Japan and, during Japanese times, cultivated largely by non-Palauans. Of these 
two are known by the Japanese names sato-imo (sugar-tuber)* and yasai-imo (vegdtable-tuber). The former, like the bisch era ruk, is a small plant with numerous tubers, only about an inch in diameter, with stems which emerge from the underside of the leaf, like kukau, rather than from the edge of the leaf like brak or bisch. The second, yasai-imo, is so called because the small tubers are not eaten, the stems are boiled and eaten as vegetables. These two, and apparently some other varieties, grow around old Japanese garden sites on Babel thuab island, and Palauans occasionally grow small stands in their own yards, transplanting from these basic stocks.

Though the gods of old Palau receive little attention today, they are recalled in the name of one final aroid, the klab ora elid (variety of calladium), literally the "taro harvested by the gods." The word klab refers to a harvested tuber, so the connotation is that this tuber, not part of the human diet, has been reserved for the kitchens of the gods. The unusually defined red pattern in the green field of the leaf not only suggested the sacred character of theplant to Palauans but has made theplant popular as a decorator in Palau and elsewhere.

* The Japanese sato-imo has been identified as Colocasia-esculenta. However, the tuber of the sato-imo is quite different from that of the Palauan kukau, the former is small (1-2 inches in diameter), round and white, the latter longish, with a diameter of about 3 inches and grey in colot. The leaves, however, are quite similar. 
Origins: hypothesis and history

In contrast with the "native" varieties of brak and bisch, kukau is provided with a detailed history of propagation in Palau. Sumed up and rather liberally interpreted, it would appear that kukau was brought to Palau from a southernly region, perhaps by persons adrift from New Guinea. These corm-bearing imnigrants on two or more occasions seem to have been adopted into ranking clans of Palau's major villages of the time, quite possibly the ranking clan of Ngulitel in southern Babelthuab, and the Ngelelkau clan of Angaur. At least these locations figure in the legends which portray the progression of kukau throughout Palau. On the hills around Ngulitel, now a deserted "god's village," dryland cultivation of kukau is said to have been practiced in the time of the gods. Propagation of kukau from Angaur, according to legend, followed the contemporary mesei or swampplat cultivation. Obviously no date can be given for these events: they occur as incidents in Palau's arigin myths.

Much more recently, Palauans have begun to cultivate some kukau on dry-land plats. This development came about at the insistence of Rrdial who, before the Germans arrived in Palau, had named his child "Ais", the Palawan pronounciation of the German "one." With the general message that Palau would experience great change, Rrdial urged the expansion of food resources through dry-land kukau cultivation, observing that 
such cultivation had been practiced once at Ngulitel. Western in his own behavior (he dressed and whistled like the foreigners), Rrdial constructed his nw garden, called together the village clubs of Ngaraard in Northern Babelthuab and managed to coerce the clearing of a large tract of land at Uleuul (selected for the significant meaning of the name: "move" or "change"). Here he hoped a garden for kukau would develop. While the gardens he promoted are called nreaol a term seeped in tradition, rather than the common synonym sers, the project failod. As predicted, Palau did experience a severe food shortage cluring the German administration because of typhoon and pest damage. Rrdial, once thought to be eccentric and prophet, is now widely accepted as the latter. Rather belatedly, Palauana now raise some dry-land kakau. The purpose, however, is experimentation with varieties transplanted from the bush and the development of new varieties from the small seeds which do not readily produce plants in the swamps. The production of kukau as a food crop is still limited largely to swamp cultivation.

\section{Social Value of Taro in Palauan Snciety}

The value of kukau in Palauan social life can be signified by the fact that, at cne time, the one article that was absolutely necessary as a possession of the female village club was the huge olketokel, a large wooden bowl, cut from a 
single log with its four or five foot bowl supported on four legs. (See Fig. 3-d, page 3I) This bowl, or tray, bought for the clubs competitively by the first or second village clan, had as its primary function the display of uncooked kukau corms, stacked within a slight bamboo and twine scaffolding to a height of twenty or thirty feet and presented as a gift in the context of a major food-money exchange.

We can illustrate the importance of kukau, and other aroids, in Palauan life through a glimpse at the life cycle of the individual with reference to his experience with taro gathering our data from the past as well as the contemporary Palauan scene.

Prebirth: When the expectant mother was in her first few months of pregnancy, the traditionally oriented Palauan parent would take her from her husband's home and provide her with special care. Where a large god's house (ulengang) was located on the homesite, she would be instelled there, without chores and with the intention to supply her with whatever foods she desired. It is reasonable to assume that kukau would have been an important part of her diet, but she might demand and get any food available that occurred to her, including the lowly brak and bisch. To accomplish this rather whimsical feeding, the father of the expectant girl would establish contracts with specialized food producers (kerreomel). This practice is almost non-existant in Palau today with the expectant mother 
attending, instead, the hospital pre-natal clinic, receiving what dietary attention and advice she needs from the doctors there.

Birth: Once the child was born, a considerable change in diet formerly was stipulated. Whereas pigeon, pig and foods cooked in oils from these were common in the pregnancy diet, the post-natal diet consisted of rigidly non-fatty or non-oily foods, the first of which would be baked kukau. This first meal was stipulated in the belief that Palauan post-natal medications would respond only if the mother first digested a small portion of baked kukau. After this first meal, the prohibition against oily foods persisted for two or three months, until the abdomen was pronounced recovered, and kukau boiled in water was an important menu item. Currently, the young mother, who has her delivery at the Government hospital, is provided meals by her near-by relatives or friends under the direction of the hospital dietitian. While soft foods are provided the first few days, no further dietary precautions are normally taken. More correctly, as one of the hospital nurses assured us: "Since Western medicines are very powerful, we completely ignore Palauan food taboos (dalassach), such as the prohibition against oily foods."

Infanthood: About ten days after the birth the young mother (especially if the child is her first) is introduced to the assembled villagers in the ngassach ceremony. This custom 
is described at length in Barnett's Palauan Society, '1 so we will not portray it at length here. It is of interest that, in preparation, the mother is inclosed for a time in a tiny bamboo frame covered with fiber mats where she is subjected to a steam bath. Steam is produced for this bath by cooking a quantity of brak corms which, boiling hot, are placed in the bamboo hut under a small bench upon which the girl sits. Herging from this Palauan-Turkish bath, dripping sweat, she is washed with fragrant leaves soaked in hot water, her body is plied with coconut oil and yellow tumeric and, thus glistening, - and rather weary - she is led to a platform where $h$ she poses for several minutes in public view. In this ceremony, kukau plays an important part as a gift, traditionally raw corms, given by members of the mother's maternal and paternal clans to the clansmen of her husband. In return the husband's maternal clan makes a money payment to the maternal clan of the exhibited mother. Incidentally, the brak tubers, used to produce the steam bath, were brought to the ngassach by women of the mother's immediate family and are given, casually, to those who brought the raw kukau. Today, where the ngassach is concurcted at all, it is common that prepared foods, usually including some kukau, will be served by the mother's side and frequently the money payment from the father's

1. H. G. Barnett, Palauan Society, University of Oregon, 1949 
side now appears as material gifts, candies or prepared foods.

The new born is occasionally breast fed or (used to be) fed coconut milk from a fiber nippled bamboo bottle until its eleventh month, at which time it was supposed to have two lower and four (or so) upper teeth. Its first solid meal would, traditionally, consist of breast of chicken, pigeon or another fowl which the infant was expected to chew for the liquid it contained. Iater, when the child first began to experiment with crawling, it was fed (with a special turtleshell baby spoon) a gruel made from the starch of the sobosobu tuber (regarded as identical to the Japanese katakuri which, in turn, is identified as similar to the European bulbous herb, Erythronium denscanis). When the child first begins to toddle, he is fed regular solid foods, including cooked and mashed kukau. Currently it is questionable if there is any regularity in child feeding. Canned or powdered milk often replaces the breast, especially where there is a tuberculous risk, but also as an aesthetic precaution (b) Chiluren are likely to be introduced to rice gruel within a month or so and very shortly after to cooked rice. Kukau may enter the diet as a regular food if they like it; some do not. Currently Palau imports considerable packaged katakuri starch from Japan, which substitutes for the starch of sobosobu (which requires considerable 
work to extract), much of this appears to go into the diet of infants.

Childhood: Once able to accompany its mother in her chores, the Palauan child would spend several hours (usually in the cool of the morning and early evening) in the swamps and gardens where there are shaded rest shacks and usually elevated play or work areas. Thus the young Palauan girl became familiar with a major function: the cultivation of kukau, brak and dry-land produce. The boy would go along until about seven, but (the Palauan male will point out) he never came to feel fondly toward the swamps as did his sister. Currently, with many young mothers employed with the government as clerks in retail shops, as maids in American homes, or as barmaids, the young child is not well acquainted with the mesei or the sers. The playground tends to be the roadway, where children become a traffic hazard, or the neighbors backyard where they may or may not be welcome.

As the child matures, he will gradually become acquainted with food-money exchange ceremonies - the nurr, the hugh, traditional and extinct feast, or the ochoraoul, the contemporary money-raising feast - and kukau has an important part as a ceremonial gift in these.

Marriage and adulthood: At marriage, which has not been very ritualized in Palau, kukau plays a small part in one 
style that is current and occasionally followed. Where the desire to marry is announced by the young man to his parents, they notify the parents of the intended. This announcement is followed by a feast, with foods prepared by the wife's mother's clan or kongbanii ("company," a group of associates rather specific to such occasions). In good style, among the foods prepared for the occaston, there should be some kukau. In response, a payment approximating a bride's price is made by the parents of the husband-to-be to the girl's parents, with costs running between $\$ 100$ - $\$ 800$, plus a Palauan piece, the kluk, valued somewhere between $\$ 50$ and $\$ 150 .^{2}$ In another practice the couple are married on one or another church service with a bachelor party preceeding and a reception at one of the local bars following. However, perhaps most common is the "trial-marriage" - with many, many trials before a union comes to be considered a marriage.

When the young man builds his house (renting is not common or appreciated, though it occurred during the Japanese administration) payment will follow the ochoraoul ceremony, with money assembled from clan and associates. Frequently, however, the conduct of the ceremony is left to a more traditionallyversed father or maternal uncle. Customarily, however, his

2. For details on Palauan money see, Robert E. Rizenthaler, Native Money of Palau, Milwaukee Public Museum, Publications in Anthropology, \#1, Wisoonsin, 1954. 
wife, through her clan or her kongbanil will hold a feastfest and produce gifts of uncooked kukau, along, sometimes, with a rival, uncooked rice. ${ }^{3}$

Throughout his mature life, the Palauan will be called on to reciprocate with assistance, food pifts, service or money the kind of assistance he received when his house was built. Again on the occasion of a public work, a community house, schocl, road-way or dock construction, the Palauan acult may be called on to provide volunteer labor; a part of the cost for materials or special skills; or food for the completion feast. Among the latter will appear rice, imported canned tuna, imprrted pickles, imported sirups, tapioca, coconut preparations, fish, and, perhaps, some boiled slices of kukau.

Death: On death it has boen traditional that the entire village attend the first service, kemeldiil, to which neighbors, nereby kin, intimate friends, and village club members will bring unprepared foods of a wide variety, including kukau corms, but also includin€ brak and, currently, quantities of tapioca and rice. The mark of death in a neighborhood is the loud squealing of a pig, getting stuck for the occasion.

3. For a concise descriftion of the ochoraol ceremony and some of the problems of construction in Palau see, Robert K. MoKnight, The Oyabun-Kobun in Palau, Anthropological Working Paper \#5, Trust Territory of the Pacific Islands, JuIy 1959. 
These foods, prepared in surrounding kitchens, will feed the wide range of visitors, some hardly acquaintances, who will attend the feast. Attendance at the kemeldiil is marked by mixed motivations. In part the individual attends with the notion that he will cheer the survivors, it is thought, for example, that a widow might die of grief if others did not step in to cheer her up. Less articulate, however, is the fear that negligence at this social occasion will result in shunning or neglect at one's own death, "one's survivors might suffer unnecessarily." Thus the feast, on these occasions, is huge and, by western funeral standards, rather pleasant。 Grief, at the kemeldiil, is in bad taste. The public objective is to cheer the remaining family through the period of shock and loss.

When the deceased has a title, complications arise with regard to its removal from the body for deposit in the heir ( or a temporary host). Kukau plays a part in this transfer only in the case of Koror's high chief, the Ibedul of the Idid clan, In this ceremony the body of the dead Ibedul, now contained in a wooden coffin (kahol) but formerly wrapped in fiber mats (bldokl), is carried on a litter by four bearers to its grave. Pausing at some designated location, the bearers wait while two adult women of the Idid clan, carrying two whole kukau plants bound with coconut fronds (dui) on their heads, pass once beneath the litter. In this action the dui (also meaning "title") is removed and the body 
is buried as a private citizen. The dui-bound kukau plants are then passed to the heir who will receive the bundles in his outstretched arms, touch them briefly to his forehead (he has donned the title), lower the kukau to his lap (the title is a heavy responsibility), and then deposit the whole slightly below his right thigh (he will be able to make the right decisions).

After the kemeldiil we can still follow kukau through three ceremonies: sisch, omengades, and cheldeduch. The sisch follows death by three days and determines the name of the god who, offended, caused the death.

Since the kemeldiil the elder women (ararmungeiung) of the village have remained assembled in the home of the deceased, traditiomally they could leave only to perform natural functions. Preparation for the ceremony begins with the making of a bouquet (the sisch from which the name derives) constructed of the best decorator flowers and brilliant leaves (e.g. klub era relid or sisch era relid the latter being a red flowered plant). This bouquet is placed on a fine blanket or fiber mat, with (today) a piece of fine cloth wrapped around its base, the whole centered among the gathered ararmungeiung. Also on the blanket are placed betel-nut parcels or cigrarettes in a number to include the deceased as well as all of his known deceased relatives. After these preparations, the nearest female adult relative (the mungulau a sisch, or "whisperer of the sisch") approaches the 
bouquet and whispers "You were killed by Uodel." The other ararmungeiung chant repeatedly: "Korngi a ngoikau" ("He took you"). Nothing happens. The mungulau a sisch then states her accusation again, only the name of another village or clan god is given. This action will be repeated until at last the name of the god responsible for the death is challenged. Then, when the accusing chant begins the leaves of the bouquet quiver, the leaves and flowers droop and, with the mounting chant, the bouquet sheds its cloth drape and performs a slow unculation during which the chant of the ararmungeiung approaches a yell and one among them is fully engaged pushing the others away from the dancing bouquet. The nature of the excitement is relief, revealment and settlement. The name of the god discovered, the nature of the dead person's crime or violation is fairly well understood, since he violated one or another prohibition associated with the named god. When the bouquet ceases to undulate, it is covered and the inhabiting spirit of the god and the arannungeiung settle down to sleep. Later the nature of the viclation will be announced and living villagers will be appropria ${ }^{\prime}$ ely warned.

Early in the morning, after the sisch, clansmen of the deceased will prepare a special dish, tiuchl, consisting of mashed kukau molded into large balls which, placed in large, 
(See Fig. 3-e, page 31)

deep orsachal/bowls will be arranged around the stone platform outside the deceased person's home. As soon as the ararmungeiung awake they uncover the bouquet and insert the base upon a pointed bamboo pole erected also on the stone platform. The god, before the first lightness of day, is expected to devour the spirit (deleb) of the tiuchl after which it is distributed for eating among the ararmungeiung.

On the twelfth day after burial the omengades occurs, during which the site of the burial is finished. The grave is decorated, or marked in a number of ways: the tradition of placing a huge flat stone over the grave (formerly located under the stone houseplatform) is still followed in rare instances, another technique is to place a series of small stones neatly around the grave, upended bottles may be used in the same way, and occasionally a low cement cap is placed over the whole grave. After this task has been completed, the participants are hos ted by the male clansmen of the deceased, and among the dishes will be the inevitable sliced kukau along with other first foods: pig, fish, etc. It is only after this ceremony that the ararmungeiung are released to go home.

On a date set at the convenience of the participants the estate of the deceased is distributed. This ceremony, the cheldeduch (literally the "di scussion", or "telling"), which may take place several months after the burial is participated in by 
leaders of the clans associated with the family of the deceased, and here, by the decree of the nearest male relative, the possessions of the deceased are distributed. Regardless of who died, as at most Palauan exchanges, the participants are feasted by the clan of the wife and a customary payment will be made by the clan of the husband. Kukau enters the affairs of the cheldeduch In two ways: it will be among the foods served by the wife's clan and, along with wife (if she survives), children, house, money, and household goods, the disposition of the household mesei and other land holdings will be settled.

Unless, as sometimes happens, the verbal decisions relative to mesei which were made at the cheldeduch are challenged in court, this represents the final relationship of the Palauan individual and the kukau. During his life history kukau has been his bread, his gift, the bearer of his title, and, for the female, the quantity and quality of kukau that she has been able to produce have become a part of her reputation.

Economic Units and the Mesei (taro garden)

As observed earlier, in Palau, only the cultivation of kukau is laden with formalized ritual. Thus, in cultivation only kukau plats are carefully planned, the planting areas plotted and named. Brak and bisch are grown more or less willy nilly. Better varieties of bisch (e.g. bis era ruk and Saipan) are grown as 
border crops and brak is planted or crops up in odds and ends of unused swamps. With respect to these latter, it is difficult to determine how much is raised or what area is consumed by a particular family. Quite the opposite is true of knkau.

The kukau plat or individual mesei, comprising, as a rough average, a single unit of about 1,500 square feet (small plats may be 250 square feet, exceptionally large ones 2,000 square feet) is bounded by an irrigation ditch, a path, a mud dyke, or a lows stone wall and is subdivided into four types of functional units: The ulecharo (literally, "to step, as in dancing, into") is located at the head or front of the mesei as determined by the directional flow of irrigation water into the mesei and the location of the pathway by which the mesei is entered. The ulecharo is subdivided into several small plats, generally 40-50 square feet each, which contain about fifty kukau plants, spaced approximately ten inches apart. These sub-units of the ulecharo serve as the main household supply, with a few tubers taken from it two or three times a week for daily consumption. It is said that for a household consisting of ten adult persons an absolute minimum would be an ulecharo which could be subdivided into four such plats, cultivated in rotation. Thus, for the individual, the theoretical minimum space would be approximately fourteen square feet with some twenty-two plants. This might hold true if 
kukau were an important starch staple in the household and not in competition with tapioca, rice, sweet potatoe, yam and some bread.

The remainder of the mesei garden is taken by reserve plantings having three named types: bluu, urars, and uleboel.

The bluu (literally: "between"), often situated just beyond the uIecharo and before, is conceived to be about twice the size of the ulecharo, i.e., averaging 80 square feet. Unlike the ulecharo, the bluu is not subdivided and constitutes a reserve planting against special order, for example, a money raising ochoraol. It is with this kind of an event (or a wedding feast, or a funeral) in mind that the bluu is planted - though the plants harvested may not come from the bluu section.

The urars (Iiterally: "boundary" or "divider") extends as a border, about five foot wide, around the $r$ emainder of the messei, forming a "U" shape. Somewhat larger in size than the bluu, it serves practically an identical function - a larger reserve supply of kukau against some special demand. It is, of course, not planted at the same time as the bluu, so that harvesting of one may be rotated against the other. In the event that there is no special demand against these reserve plantings, kukau may be harvested for household use or for incidental gifts - or for sale at local markets. 
The final type of olat, the uleboel, occupies the center of the "U"-shaped urars. Again this plat is a reserve, formerly $U$ thought of as oriented toward the huge-feast, the murr. The word, uleboel, refers to "hugeness", used commonly to designate a large flock of birds, fish, or any other huge assembly of objects. Currently the uleboel serves an economic function distinct to the times, more and more kukau find their way from the uleboel to the markets of Koror. The occasional, roughly annual, sale of the 500 square foot uleboel harvest, at the current rate of $5 \$$ per pound will bring a typical revenue of about $\$ 35.00$. Where the mesei is unusually large, the excess space will usually function as uleboel and income may rise considerably.

The following is one conception, the one that has guided the discussion of a typical mesei or garden; it should be observed, however, that the mesei comform not only to the physical lay of the land, but considerably to the whim of the cultivator. Other diagrams (from Koror, Angaur, Melekeiok) followed similar terminology (though the meaning of the words seems to be lost to most women) but were laid out rather differently:

(See Figure 1. Page No. 24) 


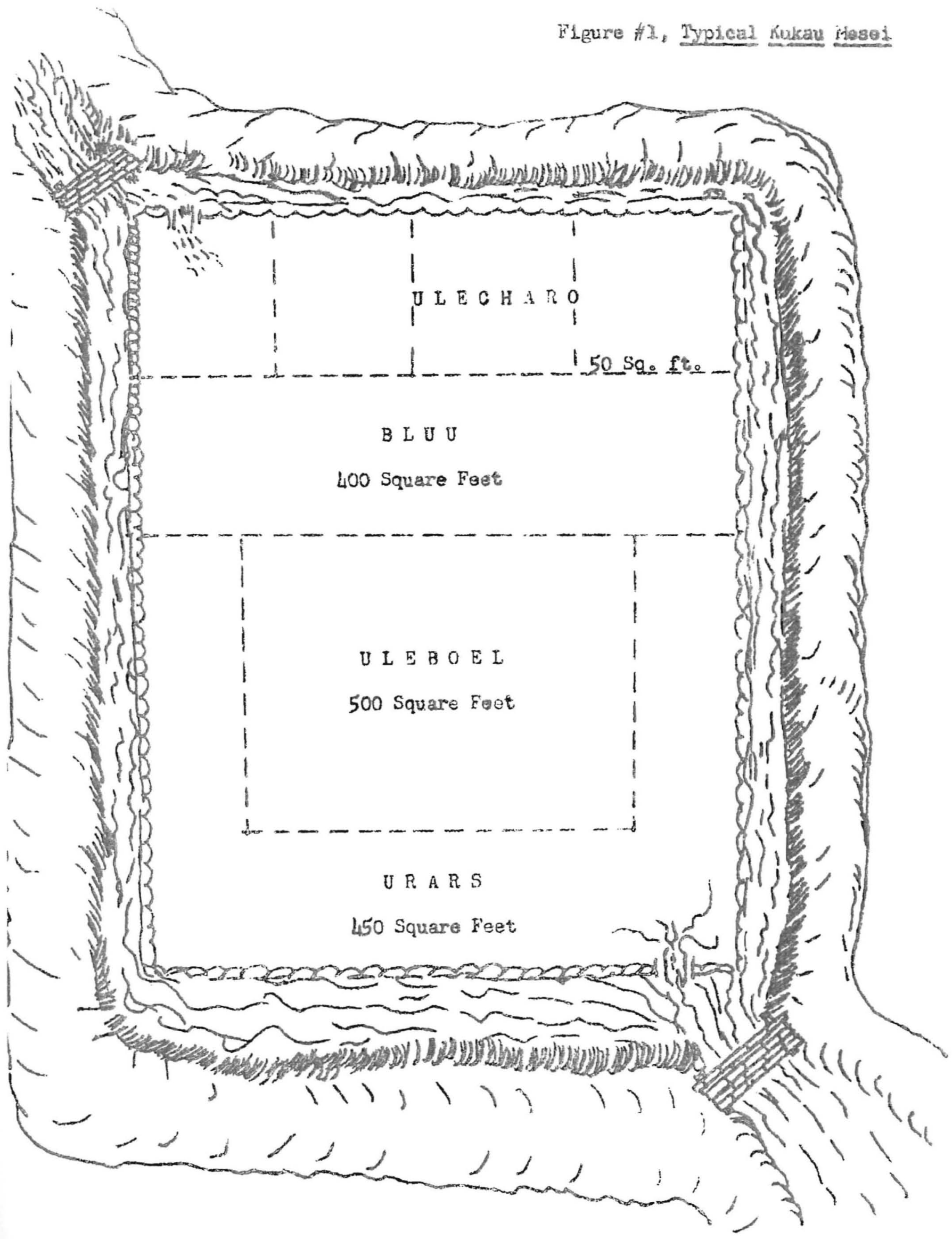


In Ngaremlengui municipality, which is dominantly peopled by followers of Modekngei (a collectivity of religious beliefs and practices founded in Catholicism and early Palauan religion) the cultivation of kukau is a church cooperative activity. There seem to be few privately owned kukau mesei in the municipality - or rather most private holdings are lent out to cultivation by this cooperative.

An area of between 10-15,000 square feet is cultivated by the Modekngei cooperative and, since a numberof persons work together, the units of cultivation are quite large. A leader of the local Modekngei sect observed that the unit of cultivation could be called "uleboel", i.e., the largest named division of the traditional mesei, but suggested that this formality in nomenclature was not followed by cooperative members. Harvests from these "uleboel" are, in part, distributed among members of the cooperative, or sold to local villagers, but the major market for the cooperative is the ochoraoul and other special feasts, with orders for quantities of kukau coming from all over Palau. Very little is reported to reach the markets of Koror.

Thus, to summarize, the typical garden or mesei unit consists of three or four types of sub-divisions each serving its special function. The smallest of these sub-divisions, the ulecharo, with an area of about 50 square feet, serves the routine 
needs of the family and a typical household might cultivate four or five such basic plats. In addition larger plats are cultivated as reserves against special demands and, more and more as marketable produce, but may be used, also, to supply routine family needs.

\section{Concitions Relevant to Planting}

Taro, in all of its actively cultivated variations, is planted throughout the year on a rotation basis. This rotation is most clearly revealed in the use of the small ulecharo plats; for example, within one garden or mesei one ulecharo will be fallow, one will be partly empty as the source of current harvest, one will be producing young branch corms, which also may be harvested; one will be filled with rows of recently planted kukau. The othersub-divisions of the garden may be in various stages: some may contain young plants with rich, erect leafage, others may contain recently planted corms with one small leaf still attached, and others, ready for harvest, may comtain kukau upon which the leaves have drooped and turned slightly yellow. Traditionally these reserve divisions of the mesei or garden would be harvested as a unit, though this practice is not followed today.

There is a "preferred season" for the planting of kukau and to understand this we must describe the Palauan concept of 
rak called "Rekil-ongos" (year-east) conformed roughly to fall and winter and the "Rekil-ngebard" (year-west) conformed to spring and summer. These "years" are determined by conditions of wind and tide and are divided by moon-phases into roughly six buill (months) as shown on the following table:

\section{Rekil-ongos (fall-winter) Rekil-ngebard(spring-summer)}

Wind: From East

Tide: Lowest at night

Rainfall: Light, short rains quickly dissipated by wind

Harvest: Most fruit trees bear heavily; tuberous plants produce light, firm corms
From West

Lowest during daylight

Heavy, lasting rains, accompanied by doldrums or light winds

Light fruit harvests; tend to be heavy, soft damp

Characteristically, though not absolutely, rainfall is lighter in the Rekil-ongos (fall-winter) and it is upon this variable that the quality of kukau corms is said to depend. Thus, with planting to harvest requiring about a year, the best time to plant kukau, for a high quality crop, is during the Rekil-ongos. With payments for the spring trochus shell harvest beginning to arrive in early fall, the months following tend to be those during which major feasts are scheduled coinciding nicely with the finer harvests of kukau. This is not to say that kukau is planted and harvested only in the fall and winter, but rather to observe that there are seasonal variations in the quality of the corms, with the preferred, light, firm corms 
planted and harvested in the Rekil-ongos. Beyond this there are few patterns in the cultivation of kukau, or other corms, which depend on cosmic or meteorological conditions, though a few elderly women still adhere to the tradition of planting all cultivated foods at the time of the full moon in the belief that harvests will thus be increased. More typically, today, planting occurs as need and convenience coincide during the early cooler morning hours or early evenings when the women work in the gardens and swamps. Harvesting, again following no particular meteorological determinants, typically occurs two or three times a week to meet household or other special demands.

\section{Soil Preparation}

The men of Palau participate in taro cultivation as landclearers using a variety of the slash-and-burn technique. The uncultivated marsh, or dechel, if it has not been utilized before (within memory) or has lain fallow for a long time, will be a dense jungle, nearly impassible with brush, the trees bearing more leaves of vines than upon their own branches and the ground moist with surface water. Fire is used, as much as possible under these conditions, in the following way:

(1) kindling fires are struck at the base of the larger trees 
gutting away a circle at the base; (2) bushes are broken in the stem to kill the leaves; (3) when leaves of the firegutted trees and broken bushes are dried, fire is struck to the area and it is burned over, and (4) at a later date the dead, dried trees may be burmed out.

Once the debris has been cleared off, the marsh was traditionally broken and turned with a four-foot, paddle-like digging stick (ongereuekl).(See Fig./ This paddle, like a knife, is first used to cut out a chunk of top-soil. Once outlined, the chunk is pried up slightly with the paddle and a partner turns the chunk over by hand. Typically this activity is conceived as being the work of a man (on the paddle) and his wife (turning over the chunks by hand). Currently a long brushknife or a straight-bladed shovel (a few are carefully preserved from Japanese times) have largely replaced the digging stick, but the organization of the task remains much the same. Stones and other debris are removed from the swamp as they are discovered, but further cultivation, in the soft mud, is not necessary before the first planting. The initial fertilizer is within the turned, fallowed soil. Thus all that remains, before the first planting, is to design the plat and its subdivisions and to tie it in with the existing plat-boundaries, irrigation system, and pathways. If these latter exist, and 
are in good condition, the plat now becomes the sole responsibility of the women.

If the irrigation system, utilizing the small streams feeding the swamp, is non-existant or in poor repair, the men are called upon to dig the ditches and pij.e the dirt walls and boundaries. Often this job is undertaken by one of the male village clubs, a complimentary women's village club serving up a feast for the occasion. Where smaller work units are undertaken, such as repair on a segment of the irrigation system or a large planting of kukau, male or female (depending on the task) neighborhood cooperatives (errakl), similar to the aforementioned kompangii, and consisting of a small, indeterminant number of friends volunterring to help one another, may undertake the task。

In some instances the flat marsh land, bordering on a natural hill-drainage system, has not been large enough for the construction of more than a very few plats. Where this is the case, and apparently in the distant past, additional plats and rather complex irrigation systens have been built up the sides of surrounding hills. While not extensive, low terrace-gardens can be found throughout Falau, especially in Koror and Ngarakabesang where natural flat swamp lands are not abundant. Till a better explanation is found, it would appear to the authors that terracing of this kind provided the stimulus which, 


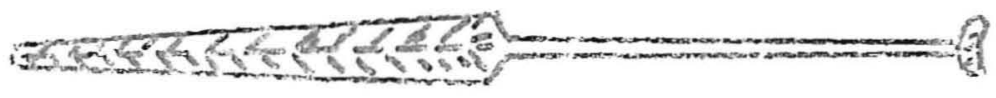

(a) Ongeruakl, wooden digeing stiok for breaking ground in kukal swamp about four feet long,

6. 20.

(b) Surubang netal digginf stiok introduced by Gemens for use in diryoland pardenthg

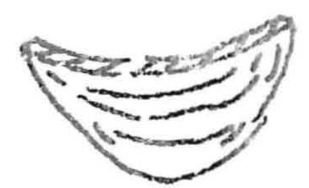

(c) Naark, peasl shell for removing akin of kuksu corm (d) 01ketoke1, hus bowl owned by fentals viluage clubs for display of new kukan corms. Bowl diameter ma be 4.5 fitet across

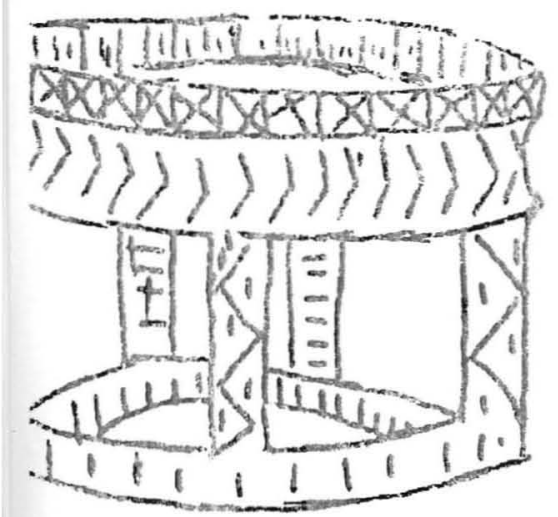

\section{(e) Crsachal, deep wood bowl for prepared dishos such as t1uch!}

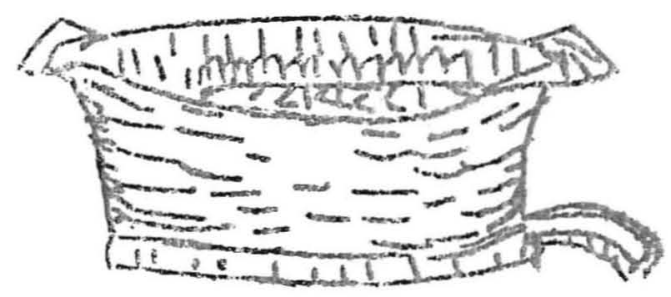


extended perhaps as a religious or military function, resulted in the many high-terraced hillsides which may be found throughout Palau north from Koror and Ngarakabesang islands.

Certainly, at one time in Palau, apparently before European contact and depopulation set in, large areas of now fallow marsh, or dechel, were under taro-cultivation. Estimates are hard to make on the extensiveness of dechel area in part because, though the dechel are probably owned, there is little tendency to include the dechel, as such, in an estimate of land holdings. The woman who permits her garden area to revert to fallow marsh, even though she may feel no need for a larger cultivated area, tends to be regarded as lazy - a poor producer for her husband's clan. There is little reason, in the Palauan agricultural conception, to allow marsh land to be fallow rather the older the re-fertilized plat, the more likely it will produce a high standard crop. If an estimate were to be made of dechel or fallow areas, however, it would appear that, taking Palau as a whole, only about 5-10\% of available marsh land is currently under cultivation. In congested Koror island, this percent would increase to, perhaps, about 50-60\%.

Interestingly, the newly cultivated kukau plat is still called "dechel", the common term for an unworked marsh. Only after considerable cultivation and several harvests does the plat come to deserve the name "mesei". Thus, kukau corms 
harvested from the new plat, the dechel, are said to have a peculiar flavor, as if some foreign element had been added to the basic taste, and the dechel only becomes a mesei when the corms are pronounced to have a pure kukau flavor. In this ideology, judging by the descriptions of Palauan sources, the well turned and fertilized mesei no longer consists of "regular earth", it is a "true kukau culture" valued because of the fine flavor produced in the corms. Once worked up to this special state, the mesei (sometimes called klool, a form of "to-plow"), turned and fertilized between each planting, is a permanent fixture. Kukau corms, in turn, are distinguished as klab era dechel (harvested corms from the dechel), and klab era mesei or klab era klool both superior corms from the true mesei. In addition, of course, there is the dry land kukau (kukau era seis) which is grown more for the purpose of propagating a new variety than to serve directly as a food.

y Dry-land cultivation of taro plants follows a fairly similar pattern though one sees few individual stands of the plants. Bisch, Japanese taros, and dry-land kukau generally occurs in rather neglected, natural appearing stands as border crops in gardens of tapioca, sweet-potatoes, or mixed among the plants in rather rare vegetable gardens. Only recently and experimently brak is being raised in dry-land gardens, again, not for eating but, like dry-land kukau, for the purpose of 
developing new varieties. Instead of the paddle, or digging stick, the only instruient associated with the cultivation of dry-land gardens is the kurubang (crowbar, a straight iron bar, pointed at one end)/distributed in German times in an effort to increase the cultivation of dry-land plants such as tobacco, yam and tapioca. Barring a few experiments with yams introduced from Yap, clearing around stands of banana trees, or tending small patches of tumeric (kesol) in natural mountain sitands, Palauans stoutly deny that there was dry-land cultivation of any plant before European contact.

The Growing Plant

The portion of taro used in $\mathrm{replanting}$ is the delomel (one central leaf attached to the top of the corm) whether the planting is dry-land or swamp. These delomel, more accurately delomel dite or taro-top planting stock, may be obtained by holding back for this purpose a part of the harvest of a particular division of the mesei, or a portion of a garden crop, or, if a new variety is to be tried, delomel may be obtained from another cultivator. Typically a popular variety of kukau in Palan will run through a cycle from the time it is discovered in the mountains or produced by dry-land cultivation to the time that it is widespread throughout Palau. By the time that a particular variety is widespread, another one or 
two will be competing in popularity and a complete census of named varieties would reveal hundreds of names: place names of origin, female names of finders, or descriptive names after the taste. At the moment, we are told, there is a popular variety ksrredel, discovered in the hills of Ngersuul, Babelthuap and named after a variety said to have been popular in arcient times because of a reported taste similarity. If kerredel runs through the typical "popularity" cycle it will last about four or five years: one year for development of the shoots byr the discoverer, one year to be spread throughout Palau, and a final couple of years as the common, popular variety. At least four other varieties are commonly grown currently: becheserak (named for a woman of Aimeliik); errderid (named after an encient variety); Ngeredukus (a mountain name in Ngardmau); and Oka ang, a lot name in Ngerechemat, Koror and a particularly useful variety since it produces a firm tuber even in the wet (Rekil-ngebard) Palauan year. Another variety, a hopeful, is called msrti and is in the first year of its popularity cycle, its reputation established largely by word of mouth. Elder sources can name many many more varieties, some no longer raised or raised now only by a few individlials or in particular locations. However women cultivators sometimes observe that there is a recent noticeable increase in kukau varieties, supposedly because of the increased use of dry-land 
experimentation with varieties found in the bush.

Similarly with increased cultivation of dry-land brak more variants are expected. A list of brak variants, believed to be fairly comprehensive, includes only eleven names (see glossary), the majority known to have a long history of cultivation and some bearing Yapese names, dating back, supposedly, to the time when Yapese men used to come to Palau to mine their stone money. Bisch, except for some recently imported aroids that go by this name, occurs in about seven varieties, but perhaps for the reason that Iittle attention is given to this unpopular, dry-land taro.

Once the shoot, or delomel, is planted, particularly if the planting is kukau or brak in the swamp, it is allowed to take for a period of about one month or until four new leaves have appeared, indicating that roots have developed to hold the plant firm. Banana leaves, laid on the ground at the time of planting, inhibit the growth of weeds for a part of this period and weeding only takes place after this initial "take". Eventually weeding is practically unnecessary as the large leaves create a deep shade over the marsh. From about one year after planting the corms may be harvested, and harvesting may take place, with branching tubers removed first, rootstocks removed last, over the next few months. When ready for harvest, as we have observed, the leaves of the kukau are no longer high 
and erect, but are somewhat shrunk and yellowed. From this the Palauan derives a proverb:

"You can tell the truly mature individual by the fact that, though his knowledge is great, like the huge corm ready for harvest, he is not haughty and proud, like the leaves of an immature kukau plant, rather he carries himself humbly and without display." When a particular sub-division of a garden or mesei is completely consumed, or the corms are removed bacause they are getting over-ripe (upon which the lower section of the corm shrivels and rots leavine only the upper part, or the ulengsobl) the mesei is ready for $r$ efertilization and replanting. Fertilization is accomplished, largely, through the use of tender, green leaves from trees, planned for this purpose and for shade, near-by the plats. Many kinds of tree leaves may be used for this purpose, but preferred varieties are: doko, 1lasch, and koranges. These, as well as telengtung which is found all ovor the islands, are worked, by hand, down into the soil between plantings. Banana leaves may be used as a soil cover both to fertilize and to inhibit the growth of weeds right after planting. With planting, the cycle of the swamp cultivated taro crop is complete. In dry-land cultivation, where the gardens are given any attention, green telengtung or humus are the preferred fertilizers, with some persons using bat guano 
collected from caves in the Rock Islands.

Magic and the myth of Milad

In former times it was common that two forms of olai (magic) were used in connection with the cultivation of kukau. "Constructive magic" or olallm consisted of the use of whispered commands or promises to the god of the individual's clan, sometimes using the medium of a betel-nut or crushed grass bundle into which the words are spoken and then thrown into the mesei - upon this a large harvest of sizable corms was expected. Currently, perhaps because gossip on this topic weakens the power of the magic, there is much more available information on the use of temall (destructive magic). The practise is similar, a curse or "prayer" being whispered into a betel-nut bundle or crushed grass and the whole tossed into a neighbor's garden. Jpon this gesture, her garden, if all goes well, will shrivel up and die - or at least the harvest will be laughable.

One source recalled an interesting anecdote in the use of temall told to him by a now dead elderly lady. Once when quite a bit younger, the elderly lady was in the act of whispering a curse into a betel-nut bundle when her clan god appeared before her with the adminishment: "You should not work destructive magic on your neighbor's mesei, you know that. However, if you 
must, then at least don't leave the telltale betel-nut exposed, cover it with a leaf". This was in Palau, in the days before Western contact and when the Palauans, as they will sometimes observe, had gods that were not all "diablong" and that participated and identified with their daily lives, taking sides and saving face along with the rest of the clan but, above all, showing the Palauan humans how best to carry out the tasks of their daily life.

The legend of Milad is of the latter sort. Starting her life with name, Iliuochel, grand-daughter of Latmikaik (mother) of Uab, the giant whose body became Palau) she was given the task, by her grandmother, to instruct the new inhabitants of Palau in the art of cultivating kukau. Iliuochel carried out her task with the following results (these results differ somewhat according to the narrator):

Angaur: She bagan her work at Angaur and did so with considerable skill and $r \in$ Jish so that the kylsau gardens of Angaur are, today, amorg the most flourishing ir all of Palau.

Peleliu: The people, in particular, could not understand her use of fertilizer and, even today, not all people in Peleliu use iertilizer in their taro gardens.

Koror: Here Ilitochel married, but quite unhappily and was satisfied to spend a great deal of her time in the mesei. Today, 
not only are Koror women reputed by some to be notoriously urhappy with their husbands, but they must spend an unusual length of time and fertilizer in the fields in order to produce a good crop.

Achol: Here, in this village of northern Babelthuap, Iliuochel took another husband (as she did at each town where she instructed) and was particularly pleased with him. Consequently she made the swamps in such a way that practically no cultivation was necessary. Even today the women of Achol find that they need use only a small amount of fertilizer and labor to produce some of the finest kukau crops throughout Palau.

Iliuochel, after a few more changes of name, is the woman who figures in the popular Palauan story-board picture showing the fish "flying" up through a tree trunk into the yard of a childless old woman. Still later, after having fed some fish, baked in kukau corms, to some tired gods, Iliuochel, now called Milad (by the gods) figured in the re-birth of the Palauan people after a great destructive flood and her children (Aimiungs, Melekeiok, Aimeliek, and Oreor) became the founders of the villages by those names.

Whether the myth was constructed "after-the-fact" or had a self-fulfilling charaster, it is quite true that the described differences in kukau cultivation exist throughout Palau. Additionally, little fertilizer is now used in Angaur, practically 
none in the northern island of Kayangel and, as we have pointed out, kukau does not grow well in Peleliu or Kayangel where more effort is put into varieties of bisch.

\section{Othrr Regional Differences: the Southwest Islands}

South of Palau, two patterns of taro use are present, one comprehending the islands of Sonsorol, Pulo Ana, and Merir (now uninhabited), the other found at Tobi, the southernmost. As a generality, throughout each of these low fringe-reefed islands, lend ownership appears to be quite individualistic and work in the fields is also an individual (or voluntary association) affair. Obviously cultivated fields occur (except for very recent extension agriculture projects) only on Tobi and, in addition, we find that the techniques of agriculture are quite similar to the low islands of Palan.

Colocasia esculenta was not grown traditionally on Sonsorol, Pulo Ana or Merir where light cultivation of natural appearing stands produces harvests of morui (Alccasia macrohiza) and burag (Cyrtosperma chamissonis).

At Tobi, on the other hand, the preferred taro is uuot (Co:ogasia esculerta) and it is grown in individually worked plats spread over the whole irsterior of the is? end. Thus, within about one hundred yards of tile beach, inland, one discovers a broad, 
sunken and leveled marsh-garden, cris-crossed by small rock boundaries and several pathways. Sections of it lie fallow, the owners living in Palau, but other sections are carefully cultivated. The path-boundaries (except for a broad road built through in Japanese times) indicate familial ownership while the small and temporary rock boundaries indicate holdings within par'sicular families. There is no irrigation system, with rain and ground water serving quite well and, in this phosphate rich soil, no fertilizer is used. It was observed, however, by Palauans that Palauan kukau, transplanted to Tobi and cultivated by Tobians, produce rather small corms. Scattered around the level marsh-garden are small hillocks, some of them seemingly terraced, or at least constructed in such a way that there is a circular path from the base to the top. These rather picturesque mounds are the product of Tobian labor in leveling and sinking the marsh land for cultivation. Theoretically, at least, if a Tobian decided today to make a new marshongarden he would call upon his closer relatives and friends and undertake this leveling project as did his ancestors. With practical sense, the hills do not become house sites because the earth, hand carried with considerable difficulty, might be pushed down again tnto the flattened marsh. As in Palau bisch (morui) and some brak (burag) are found in Tobi, the latter cultivated as a border crop along the path-boundaries of the marsh-garden. 
Glossary of Non-English Words used in text: ( $p$. Palauan; s. is in the language used in Sonsorol, Pulo Ana, Merir and Tobi.

Aramungeiung: p. elder women who remain at the home of a deceased to perform the sisch ceremony.

Bakelilei:

Bisch variety, meaning unknown, a preferred variety.

Bangbuu: p. Brak variety, meaning "bamboo".

Burag 8. Cyrtosperma chamissonis.

Becheserak p. Kukau variety, named after woman who found piant.

Belulechab p. Brak variety, name is Palauan word for Yap Islands, second preferied varlety.

Bisch p. Alocasia macrorhiza

Bldokl p. fiber mat wrapping for a corpse.

Bluu p. division of mesei, literally, "that which is in-between."

Bngei p. bisch variety, name of a highly scented, red flower.

Brak p. Certosperma chamissonis

Cheldecheduch p. final ceremony following death, literally "the telling", at which belongings are distributed among heirs.

Dechel p. uncultivated or recently cultivated kukau swamp.

Dalassch p. taboos associated with clan or village gods.

Dslome. $\quad$ p. planting stock of the various taro, including top of corm and one leaf.

Diablong p. "devil", from Spanish. 
Doko

Dudek

Dui

Ebakl

Eliiche

Emachel

Errakl

Errederid

Esel

Kahol

Katakuri

Kemeldiil

Kero

Kerredeu

Kerreomel

Kesol

Kiuid

$\mathrm{KIab}$

Klab era relid po

KIool p. a tree, the young leaves of which are used for green fertilizer

p. bisch variety, named after a type of bird.

p. common term for title and for coconut fronds.

p. brak variety named after adz.

p. bisch variety, not eaten, meaning unknown.

p. betel nut prepared for chewing.

p. male or female cooperatives that work each others swamps and gardens, as well as other reciprocated tasks.

p. ku'kau variety, meaning a rattle made from ccconut leaves.

p. brak variety, and bisch variety; meaning, a variety of thin bamboo.

p. wood coffin。

j. Japanese for a starch producing root, imported as starch in Palau.

p. first ceremony upon death of a Palauan.

p. brak variety, old word for "chest."

p. kukau variety, name of a wild flower.

p. specialized food producers contr $x$ ted for special occasions to hunt, fish and collect various demand foods.

p. brak variety, meaning "tumeric plant."

p. brak variety, work for a black, tern-like bird.

p. the harvested tuber of an aroid.

p. decorative calladium, literally "the tuber harvested by the gods." Not eaten by humans, at least.

p. fully cultivated taro swamp. 
Kluk

Kongpanii

Koranges

Kukau

Kurubang

Llasch

Mungulau a sisch

Merii

Mesei

Modekngei

Morui

Murr

Murrusch

Ngark

Ngassach

Ngeaoul

Ngeredukus p. a variety of Palauan money.

p. from "company", a volunteer association of women assisting one another at ceremonial feasts

p. a tree, the young leaves used as green fertilizer.

p. Colocasia escu?enta

p. metal digging stick introduced in German times along with the promotion of gardening. Word related to "crobar".

p. a tree, the young leaves used for green fertilizer.

p. whisperer at the sisch ceremony.

p. kukau variety, female name.

p. taro swamp, not necessarily fully cultivated, but producing kukau of "right" taste.

p. religion of Palau comprising a composit of Catholic and aboriginal rituals and beliefs.

s. Alocasia macrorhiza

p. hugh feast, traditionally given by an elite for his daughter-in-law, or by a part of the viliage clans for remaincier. Now sometimes refers to any large feast.

p. to point or crush

p. a pearl shell scraper for removing skin of kukau corm

p. coremony in which new mother is exhibited before villagers.

p. meaning garden, like sers, but seeped in tradition and respect.

p. kukau variety, place name 
Ochoraoul

p food-money exchange ceremony, commonly used to collect capital for newly built house, boat, etc.

Okalang

p. kukau variety, femalername.

Olketokel

p. a hugh bowl, or tray: upon which kukau corms were once stacked for display at large feasts.

Omerga des

p. burial place, grave, marked by large stone, bottles or cement cap.

Ongereuakl p. padjle-like, wooden digging stick for breakiıg ground in kukau swamp.

Oreachal

p. deep wood bowl for prepared kukau dishes such as: tiuch I

Oitmeiang

p. byak and bisch variety; meaning "overthrow that which is sacredc"

Rak

p. Palauan year, conforming roughly to six months and determined by conditions of wind and tide.

Rekil-ngebard p. the "year-west", or the year conforming to spring-summer.

Rekil-ongos $\mathrm{p}$. the "year-east", or the year conforming to fall-winter.

Sers $\quad$. common term for dry-garden.

Sisch p. bouquet of fine flowers and meaning a ceremony in which this bouquet "dances" by the force of god offended by a dead person.

Sobusobu

Telengtung

Terir

Tiuch 1

p. a root-tuber from which, with much difficulty, starch is extracted.

p. a bush, the young leaves, rich in nitrogen, used as green fertilizer.

p. brak variety, meaning "turtle shell spoon."

p. kukau prepared by cooking, mashing and shaping into large round balls, covered with coconut sirup. 
Uasechues

Uleboel

Ulecharo

Ulengang

Ulengsobl

UodeI

Urars

Titiot

Yars

Yubekmang p. bisch variety, meaning "broth of cooked kukau." A preferred variety

p. largest division of the kukau mesei. Word means huge.

p. smallest division of the kukau mesei, word means to step or dance into.

p. a small Palauan house, designated as a "god's house" located on the house platform. Miniatures of these are sold as tourist or handicraft goods.

p. portion of kukau plant which remains after mature corm has rotted away.

p. the Palauan village god, particularly powerful in Peleliu and Ngerekeseaul, Koror.

p. division of the kukau mesei, meaning "border."

s. Colocasia esculenta

p. brak variety, meaning "sail."

s. brak variety, said to be a Yapese explanation of surprise, a preferred variety. 


\section{TARO CULTURE AS PRACTISED BY}

\section{THE YAPESE}

\section{by}

Dai You Kim

Former District Agriculturist

and

Francis Defngin

Assistant Anthropologist

48 


\section{TABLE OF CONTENTS}

Page No.

1. Varieties of Taro grown in Yap

2. Legend Concerning the Origin of Tarom--- 52

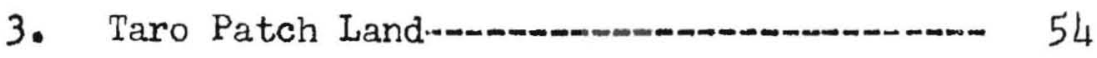

4. Method of Clearing Taro Patches-_.....-.-..- 54

5. Planting Methods-m-_-n 55

6. Methods of Cultivation-..- 56

7. Taboos observed in Taro Culture...---.-- 59

8. Division of the Taro Patches-_.......-...- 61

9. Taboos and Custcms surrounding cooking
and eating of Taro-a 63

10. Methods of cooking Taro-_an 66 
Varieties of taro grown in Yap

While several species of taro are known on Yap Island, the most popular is Cyrtosperma chemissonis, the giant swamptaro, known locally as Lek. Hundreds of Lak patches are found throughout the ten municipalities of Yap Island. Weeloay Municipality in the western section of the island is specially well known for the production of Lak.

On Yap Island six major varieties of Cyrtosperma chamissonis are grown although other varieties can be distinguished. The major varieties are known to the Yapese as Lak!' Ni Bulgumau, Lak' Ni Falan, Lak' iㅡ Ror, Lak' Ni Majang, Lak' Ni Adid, and Lak' Ni Chaz or YumYum. Of these the preferred variety is Lak? Ni Bulgumau.

The Yapese distinguish varieties by shape of leaf, size and color pattern of various parts of the plants. While the classification of taro is a complex one, it is interesting to note that the Yapese in the past, even though unfamiliar with botanical terminology, made a clear distinction between various varieties. The six major varieties of Cyrtosperma chamissonis are described by the Yapese as follows:

IAK' NI BULGUMAU

The lower part of the leaf stalk about one-third of the way up the stalk is red. The color then merges into red and green 
with the top of the leaf stalk being green. The tuber is ready for eating when the flowers bloom, even though it usually not fully matured at this time. IAK' NI BAMYIGUL

This variety has large leaves and long leaf stalks. The leaves are a deeper green than in the other taro varieties. While the tubers are large, they tend to be rather tasteless, fiberous and watery. This variety is generally used in connection with Yapese ceremonies.

LAK' NI FALAN

The lower portion of the leaf stalk is light green gradually changing to a dark green at the top. The tubers tend to be coarse and gritty (bangbang) after being cooked. The tubers are large but generally do not equal the size of the "Gamyigul" variety.

\section{LAK' NI RAR}

The lower portion of the leaf stalk is white shading into green at the top.

\section{LAK' NI MAYANG}

This variety has a different flower than other varieties. The flower has pistil which somewhat resembles a corn flower and the pistil remains after the rest of the flower has dried up. Flowers on other Cyrtosperma varieties generally do not have corm-type pistils, and the parts of the flower usually dry 
up at the same time. The Yapese wore this flower on ceremonial occasions and today the Mayang is still grown because of the unusual flower.

IAK' NI ADID

The leaf stalk is similar to that of the "Falan". This variety has a small tuber which does not grow as large as other varieties. Small leaves and a short stalk are also characteristic of this variety.

LAK' NI YUNYUM or LAK: NI CHAZ

The leaf stalk has no thorns and the leaf is tipped at the end and has thin vines growing from the back of the leaf. This variety is commonly used for marking land boundaries in the taro patch.

Legend concerning the origin of taro on Yap

Lak is an essential part of the Yapese diet and is consumed several times a day all year around. It is important also in ceremonial occasions. While many of the legends concerning taro are no longer known to the younger generation, the story of how Lak or Cyrtosperma chamissonis reached Yap is known through the tales of the old people who tell the story to the children.

In the old days according to legend, the islands of Yap were devoid of people, of taro, of coconut and of bananas. Then 
one day a ghost (ken in Yapese) appeared in the form of a human and visited the area which is now known as Keng Village in the Weeloay Municipality. There she settled down, married and $g$ ave birth to many children and also a water eel (gafiy). These children are believed to be the forebearers of the present Yapese race. As the children grew older, they took to playing in the swamps where the water eel, gafiy, lived. Whenever the children played in the swamp, the water eel bit them. The children were very much frightened and decided to do away with him and they caught and killed the water eel. That evening, the children informed their mother of this act which caused her to become very angry because the water eel was their own brother. She instructed the children to cut the eel into four sections and to plant two pieces on land and two pieces in the swamp. This the children did, and after a short period they observed a plant sprouting from the head of the eel. This plant grew into a coconut tree and to this day the nut has "three eyes". Two eyes resemble the eyes of the eel and one resembles the mouth of the eel. From the next section planted on land grew a plant which developed into a banana tree. The third section planted in the swamp developed into Mal (Colocasia esculentum) and the fourth section into Lak (Cyrtosperma chamissonis). That is how, according to the Yapese legend, the Yapese 
race and plants came into being on Yap.

\section{Taro Patch Land}

Taro patches are prepared from four types of land: small land parcels, swampy depressions, artificial depressions and areas formerly under the tide water mark. Most of the taro patches consist of land reclaimed from the sea. Reclaiming land from the sea was started many years ago when Yap was densely populated. Irand is still being reclaimed today by filling in areas near the sea with trash. Since World War II, shell holes have been used for growing taro. Some of the ancient tairo patches in Yap have not been cultivated for many years.

\section{Mathod of clearing Taro Patches}

The grass is cut out of the taro patch and hung on nearby trees and bushes to dry after which it is spread over the patch to provide humus for the plants. Trees, bushes and overhanging branches are left in or near taro patches to provide shade for the taro plants until the plants are about four or five feet high. Drainage must be provided since the taro plants will not survive if the water rises about two feet in the patch.

After planting, grass is permitted to cover the taro patch and then is cut. This practice is repeated until the taro 
plants are about five feet high after which the grass is weeded out regularly. When cormlets begin to sprout, soil between plants is spread around the base of the taro planto The practice is repeated when the tuber becomes visible. This practice results in the taro plant developing fewer and smaller leaves and makes the tuber grow upward rather than downward into the earth.

\section{Planting Methods}

The planting methods for the propagation of the taro are similar in many ways to methods employed by islanders of other parts of Micronesia, Melanesia and Polynesia. The common practice on Yap in propagating this specie are as follows: cormlets (off-shoots arising from the parent corm) or the matured plant itself are used as planting stock.

When the cormlets are utilized as planting materials, they are separated from the parent corm and the leaves cut off except for two or three of the younger leaves. These trimmed cormlets are ready for immediate planting or may be retciined for a few days before planting. The mother plant hole is filled with taro leaves and soil before planting the cormlet. If the cormlets cannot be planted immediately, several taro leaf stalks are inserted in the hole to indicate that cormlets will be 
planted at a later date. There is an old Yapese saying, "Harvest one crop and be sure to plant two."

Sometimes a mature plant will be used as the planting stock. In this case, the corm is separated from the plant with a sharp knife or machete. Usually about a fourth to a half inch is left as root stock. The leaves are cut off excepting for two or three yourger leaves. Certain villages on Yap do not utilize the matured plants for propagating materials but use only cormlets, the people maintaining that cormlets make better propagating stock. As in the case of cormlets, the planting stock may be either planted immediately or retained for a few days before planting.

In diier plots, when the parent plant is used as seed-stock, the corm is removed as described above, but one of the older leaves is bent downward and wrapped around the base of the cutm ting. The thought behind this method is to provide the plant with organic material during the early state of growth.

There is no ceremony in any form involved during the planting or harvesting of the taro by the Yapese as it is often practiced in other taro producing areas.

\section{Methods of cuItivation and harvesting}

In the past a method of cultivation involved the clearing and weeding of the swamp; then Mal (Colocasia esculentum) was 
planted in the cleared area and a day or two later Lak (Colocasia chamissonis) was interplanted with Mal. Within a year, the Mal was harvested and the patch woeded again, and a new planting of $\mathrm{Mal}$ was again intercropped with the orlginal planting of Lak; a year later Mal was harvested and the same process was repeated. After this third crop of Mal, Lak was allowed to grow by itself for a year. This cycle of planting and harvesting Mal took three years. This method of interplanting Mal and Lak is not as common today.

After "Lak" has grown for a year, it can be eaten. The corm, however, is small and the flavor not as good as older "Lak" according to the Yapese.

Work in the taro patches is usually done during the early part of the day or late in the evening when it is cool. The women wear a special skirt made of banana and palm leaves which is drab and not as colorful as the skirts worn during feasts or other special events. The men usually wear a plain cotton loin cloth (thu). In cleaning out the patches, only the older women or very old women are allowed to clean out the section held by the head of the family unit. Younger women are allowed to clean out their own patches but are forbidden to clean out patches belonging to the1r father, mother, older sister or older brother. If this custom is flouted, the belief is that 
the corms will fail to develop. In certain villages, only the very old women and middle-aged men are allowed to weed, plant or harvest the crop once an initial planting has been done. They are the only ones that are permitted to carry out work required in the old men's patches. This custom is still being maintained in certain villages.

One of the ways in which the Yapese determine whether a crop is matured for harvesting is when the plants bear flowers. Ordinarily, the taro is harvested four years after planting. A taro plant can last ten years and even mach longer and provide food for three generations if allowed to grow contimally. Certain varieties of taro if left for a considerable number of years will reach enormous proportions and tubers may weight as mach as two to three hundred pounds and may require two men to dig and carry it out of the patch,

The harvesting of taro is governed by the people's needs and only the amuunt that can be consumed in a week's time is harvested. Thus there is constant harvesting and replanting going on simultaneously in a single patch.

Tools commonly used for digging tubers are long knives and a prying stick, the "Bcrowo" or "Yajwoo." This is made from the betel palm and shaped something like an oar. The method of harvesting is to separate the cormlet from the mother piant and to 
remove all roots from the water.

Taboos observed in taro culture

A number of strong taboos and restrictions surround the cultivation of taro as well as its preparation for food. These taboos are known in Yapese as "dachmach tabgul". These restrictions fall under several categories.

Food Taboos

During the preparation of the taro patch for planting, workers are forbidden to eat any cooked food the night prior to working in the fields. The only food usually consumed by the Yapese curing this period are fruits in raw state, copra, and drinking coconut. Cooked foods are "taboo", the Yapese holding that the taro plants will "burn up" if such foods cooked over a fire are eaten.

$\underline{\text { Sex Taboos }}$

Both men and women are forbidden to engage in sex activities when engaged in planting or cultivating taro. This restriction begins the night prior to the day when the taro patch will be worked and continues for a three, nine-day cycle after the completion of the planting for a total period of twenty-eight days of sexual restraint. It is believed that if an individual violates this taboo on sex, 
the corms of his newly planted taro will fail to develop.

During her menstruation period, a woman must stay away from the taro patch completely, for the Yapese fear the taro patch will be contaminated and result in the poor growth of the plants. After the completion of her menstrual period, she is still restricted from entering the taro patch for an additional three day period. After this period the taboo is lifted and she is allowed to work in the patch.

Young girls ordinarily do not work in the taro patches until they have reached the age of puberity. The "taboo" described above is followed even more strictly for younger women. It is generally not until a young girl has had her initial menstruc l period and has been schooled in all the customs and taboos does she begin to raise taro.

Traditionally also, immediately after the planting of a new crop, the workers were often restricted from entering the taro patch for a period of six months, even for necessary tasks as wəeding or replacing poor stocks. It was held that disturbing the plants so early would result in poor corm formation. This is not followed to any major extent today. The taboo on women entering taro patches during certain periods is stronger in some areas than in others. While in most Yapese municipalities, the restriction generally affects 
women during the menstrual period, in Tomil Municipality and to a certain extent in Gagil, women are forbidden to enter at any time certain patches. As a result of this stronger taboo, in these two municipalities men carry on more activities in taro culture than elsewhere on the island of Yap.

Dirrision of the taro patches

A taro patch in Yap known as mout nay vary all the way from the size of a desk top or an area equal to that of four baseball fields. Nearly all of the larger patches are divided into individual patches. A taro patch owned by several families may still be further subdivided into individual plots within the families. Often there are separate taro patches located some distunce away from the family patches and these are usually reserved for the old men of the villages.

The Yapese have a legend which explains how the division cf the taro $p$ atches came into being. The division of the taro patch in'o ina:vidual and family units was started by a man named Kee Mel who came from a legendary island called Sepin which was located off the island of Rumung near the village of Ganaun. According to the legend, Kee Mel possessed great megical powers and was responsible for teaching the Yapese how to build their foundations of their homes in section. Whenever 
he stepped on the various islands of Yap, that section was to be marked off. In this way all the land in the islands was divided into sections. The people complied with his wish being afraid of his great magical powers and divided the land and assigned a particular parcel to individuals according to rank, age and sex. It was thus that the division of the taro patches came about. The sectioning or diviston of the taro patch into family and individual units have been practiced from the time of Kee Mal and has been followed by all succeeding generations. The division of the village patch into family units and family units into individual units differs slightly between the municipalities due to local customs and traditions. Different villages have their own customs and may vary from village to village. The boundaries (togol in Yapese) enclosing the family or individual plots (mout) are usually marked off with rocks or any outstanding landmark. Every individual knows his or her taro patch boundary and that of his neighbors and there is no such thing as taking corms from another plot by "mistake".

Stealing from a neighbor's patch is considered a very serious crime and the guilty person may have to forfeit his entire taro patch or even his section of land. If the crime is judged to be serious enough, he may even be banished from the village. 
Taboos and customs surrounding cooking and eating of taro

A number of stringent taboos exist in Yap with respect to cooking of food and the eating of it. While these taboos are not as strong as formerly, they still are followed to a great extent. Many of the taboos described below pertain to preparation and consumption of foods in general, not only to taro.

A male member within a family will bring in the taro to the woman who is the head of the household for cooking. There is a special cooking pot for each family member. The woman wears a special skirt for cooking and changes to another each time she cooks for an older member of her family or her husband. The separate skirts and pots are essential to avoid contamination of the food, for the Yapese belleve that such contamination will bring about a premature death for one of the members of the family. The custom of having separate pots for different sexes and ages within family resulted from the practise of strict segregation of age groups in traditional times.

This segregation into age groups is known as Douach. Only male members are affected and every male when he reaches a certain age is elected to or assigned to a particular Douach. Seven classes exist today in Yapese society and the douach serves 
as a category within the caste system. Usually, the caste system is formed along the ranking of a village within a municipality. Accordingly in Yap today each villaze has a certain rank or prestige within a municipality. The villago to which a person belongs determines his or her rank in the caste system. There are high and low class villages with intermediary classes between the two. As in the ranking of the villages, there is also a definite ranking among the ten municipalities on Yap.

The assignment of a young Yapese male to a particular category or class in the Douach is usually determined by the village Chief, the village Elders and the father of the young aspirant. Usually, a male is eligible to join the Douach upon reaching fifteen years of age.

There are three divisions or categories in the Douach. They are as follows:

a. Garkuf group which is the ranking group.

b. Mazeeg group which is ranked next to the Garkuf group.

c. Pitoruw group which is the lowest class in the duach. Election to the Garkuf group means prestige and mostly ranking members of the village are elected to this category. Once a person is elected to the Garkuf group, he is forbidden to eat with members of the opposite sex or younger 
members of hisown sex. He may give food to persons in the ria Mazeeg group but not to the Pitoruw group members.

On the other hand, election to the Mazeeg group means he may be allowed to eat with members of the Garkuf group but not with members of the Pitoruw group. He is allowed to give food to the Pitoruw group but cannot offer food to members of the Garkuf group. As in the case of the Garkuf group he cannot eat with members of the opposite sex and younger members of his own sex.

If elected to the Pitoruw or lowest group, he cannot offer food to either the Garkuf or the Mazeeg members. He cannot eat with younger members of his own sex and with the opposite sex.

Each village could organize their own duach groups except the lowest class people (e.g. the Maliguy ni Kan) which is the lowest class in the present caste system of today. However, the Malinguy Class which is higher than Malinguy ni Kan in the caste system is permitted to form a duach amongst themselves. All classes above Malinguy ni Kan are permitted to form Duachs.

While Yapese women are not so strictly hedged with taboo patterns regarding food, older women are forbidden to eat with younger women. 
Children are somewhat exempted for during early childhood, children of opposite sex may eat from the same cooking pot. Children, as a rule, also can receive food from middle aged men and all women. Restrictions for a girl sets in with puberty or with her initial menstruation. From this time on she is forbidden to eat with members of the opposite sex of her own age or with older males.

Often, in a Yapese home (tabinaw) there is a section allotted for cooking purposes for the old man of the household. For therest of the members in the family, the cooking is usually done out in a cook shed (peanifiy) which is located a short distance away from the home. In a large family, there may be two or three separate cook sheds because of the differences in age and sex among the members of the family. The general custom is for the older members to cook in a separate shed away from the younger members of the family.

\section{Methods of cooking taro}

There are various ways which the Yapese prepare taro for table use. One common method is to peel off the skin, cutting the corm in small sections either to fit the container or to accelerate cooking. The taro is boiled in water for about an hour which is the required time for cooking. Often a tuber, 
if not cooked immediately after harvesting, begins to form bitter spots called buyub. Two techniques are used to remove these. The outer skin of the tuber may be peeled off, the spots dug out and the tuber sections soaked in sea water for several hours before cooking. A more common method, however, is to leave spots but to add instead several mashed Polynesian chestnuts (buoy) to the tuber pot. This takes away the bitter taste.

Although today many Yapese use metal pots for cooking instead of the former clay pots, a metal lid or cover is not used. To cover the pot a taro leaf is used, the Yapese holding that this makes the corms taste and smell better.

The corm may eaten plain after cooking or coconut milk may be added for flavor. The cooked corm is called Lak' Ni Malum, and often is mashed and mixed with grated coconut.and sugar. Another method of preparing the corm is to slice it into thin slices and fry them in deep pork fat. Sugar is generally added to these fried slices to give them flavor. A taro dumpling called "yougil", is also made by mixing pounded boiled taro with grated coconut and coconut cream. . Leftover boiled taro is mashed, mixed with grated coconut or coconut cream and boiled. This forms a dish called gilipagil. Leftover taro may also be sliced and boiled in coconut cream forming 
a dish known as yipchig. Taro may also be roasted but this method is not used commonly tocay since roasting the corm takes a long time. 